\title{
Behandlingsmotivation och tvångsvård
}

\author{
ANDERS BERGMARK \& LARS OSCARSSON
}

\begin{abstract}
Tvångsvård av vuxna missbrukare syftar till att motivera individen till att frivilligt sök a behandling för sitt problem. Den teoretiska basen och de faktiska formerna för ett dylikt arbete har dock i huvudsak förblivit oklara eller oartikulerade. Är tvångsvårdens praktik relaterad till vetenskapligt etablerade perspektiv på behandlingsmotivation?
\end{abstract}

Möjligheterna att tvångsvårda missbrukare regleras i lagen om vård av missbrukare i vissa fall, LVM (SOU 1987:22; prop 1988/ 89:147). Huvudman för tvångsvården är sedan 1 april 1994 en nyinrättad myndighet, Statens Institutionsstyrelse, SIS. Tvångsvården kan utan någon större mått av tvekan betraktas som kontroversiell i den meningen att den framstår som avvikande i jämförelse med andra västländers arrangemang beträffande interventioner för vuxna missbrukare, samt att de mer artikulerade grunderna för verksamhetens legitimitet framstår som bristfälliga. ${ }^{1}$

I en rapport från en nordisk forskargrupp

Anders Bergmark är professor i socialt arbete med inriktning på vård och behandling av alkohol- och drogmissbrukare vid institutionen för socialt arbete, Stockholms universitet.

Lars Oscarsson är professor i socialt arbete vid institutionen för samhällsvetenskap, Örebro universitet konstaterades att Sverige intar en särställning också bland de nordiska länderna (Järvinen \& Skretting, 1994). Detta gäller såväl utformningen av de lagar som reglerar tvångsvården som föreställningarna hos de praktiker som skall initiera densamma. Beträffande det första förhållandet kan vi konstatera att kriterierna för tillgripande av tvångsvård är de mest vidsträckta samtidigt som såväl det faktiska antalet institutionsplaceringar och tidsomfattningen också ligger i topp (Lehto, 1994). När det gäller tvångsvårdens legitimitet bland de berörda praktikerna framstår de svenska socialarbetarnas tilltro till s.k. paternalistiskt tvång som tämligen unikt. Det paternalistiska tvånget, ett tvång som riktas mot en be-

1 Tännsjö (1994) har, med hjälp av fackfilosofens begreppsapparat, granskat de etiska aspekterna av LVM-vården och därvid funnit att den inte kan betraktas som försvarbar. 
slutskapabel individ med hänvisning till individens eget bästa, har till skillnad från ett s.k. utilitärt tvång, som syftar till att skydda tredje man, nästan inga försvarare bland praktikerna i de övriga nordiska länderna.

Den tvångsvård vi här diskuterar stannar inte vid en föregiven akut livräddande eller livsuppehållande funktion, utan syftar till att motivera missbrukaren till att frivilligt söka behandling. Vårdtvånget skall upphöra så snart detta syfte är uppnått, dock senast efter sex månader. Det har angivits att tvångsvården i denna mening endast har karaktären av ett motivationsarbete och inte skall uppfattas som en långsiktig behandlande eller rehabiliterande insats i sig (SOU 1987:22). Detta resonemang, lagstiftarens boskillnad mellan motivation och behandling sätter inte bara motivationsbegreppet i fokus, det medför också att det framstår som rimligt att efterfråga vilka skillnader, om alls några, som finns mellan behandling och motivationsarbete.

I denna artikel avser vi att diskutera och analysera vetenskapligt etablerade perspektiv på motivationsproblematik med en tydlig relation till behandlingsarbete med missbrukare. Därvid syftar vi inte - i linje med den konventionella formen för en översiktsartikel - till att i första hand frilägga samtliga delar av detta fält. Fokus är istället inriktat på att identifiera de dominerande perspektiven $i$ den vetenskapliga diskursen kring missbrukares behandlingsmotivation och därvid också analysera de bärande elementen hos desamma. Detta arbete är avsett att etablera en plattform för en bedömning av de arbetsformer som motivationsarbetet har fått inom den vård av missbrukare som genomförs med stöd av LVM.

\section{Vad är motivation?}

I sin mest grundläggande form framstår innebörden hos begreppet motivation som ytterligt abstrakt och mycket nära vad vi skulle kunna beteckna som en grundläggande dimension för beskrivning av mänskligt beteende. I det senaste stora svenska uppslagsverket definieras motivation som en "Sammanfattande term för de processer som sätter igång, upprätthåller och riktar beteendet (Nationalencyklopedin, 1995, volym 13, s. 274). Även om vi här inte avser att fördjupa oss i ett mer brett urval av olika definitioner på denna generella nivå, kan det ändå var av värde att hålla i minnet att motivationsfrågan berör individens hela handlingsrepertoar, en omständighet som ofta hamnar i skymundan i de framställningar som rör alkohol eller drogmissbrukares motivation.

Intresset för missbrukarens motivation är endast undantagsvis riktat mot att förklara varför individen faktiskt upprätthåller sitt missbruk. Det är istället frågan vad det är som kan få missbrukaren att ändra på sitt handlande som står i centrum. Därmed tangerar problemställningen ofta också mer eller mindre renodlade behandlingsfrågor. Konkret avspeglas detta i att det inte alltid är klart huruvida olika författare anser att det finns en skillnad mellan motivationsarbete och behandling.

I den fortsatta framställningen avser vi att huvudsakligen diskutera de mer specifika innebörder och avgränsningar motivationsbegreppet har givits i den vetenskapliga litteraturen på missbruksområdet. Till detta kommer dock ett antal utvikningar i riktning mot generella teorier som på ett el- 
ler annat sätt knyter an till de problemställningar som behandlas inom missbruksområdet. Vi tänker här i första hand på vissa delar av s.k. "rational choice theory".

En dylik begränsning av vår uppgift innebär emellertid inte att det också är oproblematiskt att etablera en entydig uppfattning beträffande begreppets omfattning och innebörd. Det föreligger en betydande divergens mellan ett antal dominerande perspektiv, samtidigt som det också finns en del ıinterna» oklarheter inom olika skolbildningarna.

Med hjälp av sedvanliga litteratursökningar i ett antal större databaser kunde vi tämligen snart konstatera att även om det fanns ett betydande utbud av artiklar och böcker inom området, var flertalet relaterade till ett mycket begränsat antal grundläggande perspektiv eller »skolbildningar".

Det kanske mest inflytelserika perspektivet på motivationsfrågan - bland praktiker och forskare - kan inordnas under beteckningen "Motivational Interviewing». Den främste representanten för detta perspektiv, Miller, hävdar med emfas att motivation inte bör betraktas som en egenskap hos klienten utan istället bäst gestaltas som en "dynamic interpersonal process involving therapist and environmental as well as client determinants" (Miller 1985, s 100). I mångt och mycket tycks denna ståndpunkt ha artikulerats i opposition mot två centrala teser med anknytning till Anonyma Alkoholister (AA) och behandlingpraktiker med nära relation till AA:s ideologi. Det gäller dels AA:s tes beträffande "hitting bottom" som en mer eller mindre nödvändig förutsättning för en mer genuin förbättring (recovery) och dels tesen om förnekandet av närva- ron av problem som ett centralt drag hos alkoholproblematiker. Miller (op. cit.) hävdar att dessa båda teser tillsammans bygger upp en modell som beskriver motivationen som en egenskap hos individen, och vidare, att denna modell i sig kan tolkas på två olika sätt. I ett första fall hänvisar Miller till att ett stort antal författare har beskrivit modellen som en lätt maskerad variant av ett traditionell moraliskt perspektiv som lägger skulden på missbrukaren - att missbrukaren kan lösa sina problem om han eller hon verkligen vill. Den alternativa tolkningen av "egenskapsmodellen« innebär enligt Miller att individen uppfattas som oförmögen att överhuvudtaget kontrollera sina handlingar - missbrukarens bristande motivation betraktas som en direkt manifestation av en konstitutionell/fysiologisk defekt (Miller op. cit., s 85).

Vi ställer oss dock aningen tveksamma till Millers karakteristik. Det är t.ex. oklart på vilka grunder ett moraliskt perspektiv kan betraktas som mer egenskapsorienterat än den hållning som Miller själv företräder. Om vi anlägger att moraliskt perspektiv på en missbrukare som erbjuds en behandling som personen ifråga avböjer, betraktar vi väl knappast denna "brist på motivation" som ett uttryck för en egenskap. Med det moraliska perspektivet följer väl istället att vi ser individens hållning som ett val vilket är möjligt just på grund av att missbrukarens motivationstruktur inte har karaktären av en permanent egenskap.

Inom Millers egna teoretiska ramverk har motivation definierats i termer av sannolikheten för att individen skall uppvisa specifika beteenden. Miller \& Rollnick (1991) beskriver sig själva som pragmatiker när de 
anger att motivation kan förstås som "the probability that a person will enter into, continue, and adhere to a specific change strategy" (s. 19). De understryker att denna definition medför en långt driven kontextualisering av motivationsbegreppet, och att frågan om motivation därmed förskjuts från missbrukaren till terapeuten. Det är inte svårt att se att Miller \& Rollnick pekar på ett högst central omständighet när de betonar att motivation alltid måste bedömas i sitt kontext; en narkotikamissbrukare kan t.ex. framstå som helt omotiverad i relation till en traditionell institutionsbehandling, samtidigt som det motsatta gäller för behandling med metadon.

Därmed är dock inte sagt att Millers och Rollnicks hållning är problemfri. Betoningen på terapeutens eller behandlarens ansvar för klientens motivation utgör en indikation på att de tycks ha en blind fläck beträffande det faktum att de alltid utgår från ett behandlingsperspektiv. Under det att förespråkare för ett mer AA-inspirerat perspektiv på motivation kan hävda att det är meningslöst att närma sig en alkoholproblematiker med behandlingsinitiativ innan denne har "slagit i botten", helt enkelt därför att detta också medför att denna person inte vill sluta dricka, tycks Miller \& Rollnick utgå från att alla missbrukare egentligen vill ha behandling, problemet är bara att många av dem har ännu inte insett detta behov

Inom den kliniska sfären utgör den AAinspirerade hållningen huvudalternativet till det perspektiv som framförts av anhängare till "Motivational interviewing" (och Prochaska \& Di Clementes Transteoretiska modell, som har ett relativt nära släktskap med "Motivational interviewing» och som kommenteras i den fortsatta framställningen). Betoningen ligger här i första hand på vad som kan betecknas som problemperceptionen, dvs individens uppfattning kring konsekvenserna av det egna alkoholbruket. Det är dock möjligt att urskilja ett antal undervarianter på detta grundläggande tema. I några fall gestaltas alkoholproblematikerns bristande motivation som en direkt följd av ett förnekade av problemen och där detta förnekade betraktas som en försvarsmekanism i mer traditionell psykoanalytisk mening (se t.ex. DiCicco, et. al., 1978).

I andra fall anges mer biologiska orsaker till det faktum att individen envisas med att inte vilja "erkänna» sitt problem - att individen saknar kontakt med verkligheten och har ett försvagat omdöme på grund av walkoholismens natur» (Maxvell, 1981; Johnson, 1973).

En av de mest teoretiskt intressanta uttolkningarna av AA:s tes om nödvändigheten att "slå i botten « har framfört av Bateson (1973). Batesons analys identifierar en grundläggande skillnad mellan följderna av problematiseringar »ovanför individens botten" och följderna av en genuin »botten-erfarenhet". I det förra fallet tenderar individen att reagera på ett sätt som enbart tillfälligt leder till förbättring eller nykterhet. Om det t.ex. i första hand är alkoholproblematikerns omgivning som står för problematiseringen, tenderar detta få till följd att individen ifråga skär ner sin konsumtion eller helt slutar, men bara intill den punkt som det är nödvändigt för att visa att detta faktiskt är möjligt. När detta är gjort kan individen återuppta sin tidigare konsumtion. Samma mönster är också möjligt även om det är alkoholproblemtikern själv som är källan till 
problematiseringen. Så länge som det inte är frågan om en problemupplevelse som leder till att individen "slår i botten" kommer individen att organisera sig själv på ett symmetriskt sätt visavi sin omgivning, vilket i princip betyder att han eller hon kommer att avvisa varje beteckning som antyder det motsatta, i detta fall en beteckning som anger en avvikelse beträffande förmågan till en problemfri alkoholkonsumtion. Enligt Bateson är en »botten-erfarenhet« själva utgångspunkten för en radikal re-organisation av individens förhållningssätt till sin omgivning, från en symmetrisk hållning till en komplementär, vilket bl.a. innebär att individen ger upp sina försök att "vara som andra" och istället regelbundet (dvs. på AAmöten) reproducerar sin egen avvikelse (jag är alkoholist) för att bibehålla sin komplementära relation till sin omgivning (jag kan inte, som andra, kontrollera min alkoholkonsumtion). ${ }^{2}$

Vid sidan av de mer kliniskt orienterade inriktningarna återfinns också ett antal försök att utveckla instrument för att mäta behandlingsmotivation. De Leon et. al. (1994) har lanserat ett instrument innehållande följande fyra delskalor: omständigheter (definierat som yttre tryck); motivation (definierat som inre tryck), inställning till behandling; och lämplighet för behandling. Simpson \& Joe (1993) har vidareutvecklat en tidigare version av De Leons instrument (De Leon \& Jainchill, 1986) och därvid re-

2 Det kan var på sin plats att påpeka att en »botten-erfarenhet« ingalunda måste var av extrem natur, inom AA grupper återfinner man ett språkbruk som antyder ett relativt brett register; från låg till hög botten (se t.ex. Maxvell, 1981) ducerat omfattningen till tre delskalor: problemperception, upplevt hjälpbehov och inställning till behandling. Även om det finns en viss glidning mellan de olika komponenterna i dessa båda skalor tycks det oss som att de i huvudsak adresserar vad vi skulle kunna beteckna som tre grunddimensioner hos begreppet behandlingsmotivation: Individens perception av sitt problem och dess konsekvenser, individens tilltro/acceptans av en given behandlingsform och individens uppfattning beträffande den egna förmågan att genomföra denna behandling. En dikotomisering av dessa dimensioner ger 8 möjliga kombinationer, varvid endast en med säkerhet skulle leda till en klients frivilliga involvering i behandling (ett bejakande av såväl problem, tilltro till behandling, och den egna förmågan att genomföra behandlingen). I de övriga sju fallen framstår behandling - utifrån individens perspektiv - som ett icke-rationellt handlingsalternativ.

Simpson och Joe (op. cit.) ansluter sig likt många andra på området - till ett teoretiskt perspektiv som anger en sekventiell ordning av behandlingsmotivationen. De betraktar den egna modellen som en rimlig ekvivalent till de mer omfattande anspråk som framförts av Prochaska \& DiClemente (1984). De hävdar att problemperceptionen kan relateras till de förändringstadier som Prochaska och DiClemente betecknar som "pre-begrundande» (precontemplation) och "begrundande" (contemplation) i den meningen att ett förnekande av problem utgör den första hindret i en utveckling mot förändring. 


\section{Motivation som förändring - Prochaska och DiClementes modell}

Prochaska och DiClemente (Prochaska, J. \& DiClemente, 1984) lanserade i början av 1980-talet sin s.k. "transteoretiska modell" för förändringsprocesser, numera mest känd som deras stadiemodell (stages of change). Få om ens någon annan teoretisk konstruktion inom missbruksområdet har rönt en sådan påtaglig och of ta förbehållslös uppskattning som denna modell. De mest entusiastiska har förhållit sig till en av modellens senaste förändringar - tillägget av ett femte stadium (preparation) - med samma vördnad som kan tänkas beledsaga upptäckten av en ny planet (Stockwell, 1992).

Grundtanken hos Prochaska och DiClemente är att individens förändring går via ett antal stadier som följer på varandra i tid. Utgångspunkten utgörs av ett "pre-begrundande» tillstånd (precontemplation), då individen överhuvudtaget inte tänker på att förändra sig eller till och med är helt ovetande om förhållanden som senare kan komma att uppfattas som problematiska. Från detta stadium påbörjas en förändringsprocess när individen övergår till att "begrunda" sitt problem (contemplation). Via ett "beslutande" stadium (preparation) övergår sedan individen till att iscensätta sin förändring i ett "handlings" stadium (action), vilket över tid övergår till ett tillstånd där individen upprätthåller den förändring som har genomförts (maintenance). Om individen inte återfaller till sitt tidigare beteende och får börja om i modellens lägre regioner, lämnar han eller hon densamma (termination) och har då slutgiltigt genomfört sin förändringsprocess .
Prochaska och DiClementes modell har operationaliserats dels via en s.k. »staging algoritm och dels via en mer elaborerad skala - »The stages of Change Questionnaire« vilken ibland också betecknas som URICA (akronym för University of Rhode Island Change Assessment) och den mer alkoholspecifika SOCRATES (Stages of Change Readiness and Treatment Eagerness Scale). Algoritmen bygger på fyra item som ligger till grund för en indelning i modellens fem olika stadier, där varje brukare (rökare, droganvändare osv.) eller före detta brukare entydigt kan hänföras till ett stadium enligt följande: Pre-begrundande, brukar och inga övervägda planer på att sluta inom 6 månader; begrundande, brukar men överväger att sluta inom 6 månader, men inte att (1) sluta inom 30 dagar och/eller (2) har inte genomfört ett åtminstone 24 timmar långt försök att sluta under det sista året; beslutande, brukar men överväger att sluta inom 30 dagar och har gjort minst ett försök att sluta under det senaste året; handling, ej bruk, slutat för mindre än 6 månader sedan; upprätthållande, ej brukare, slutat för mer än sex månader sedan.

Indelningen i de olika stadierna är i huvudsak baserad på individens bruk/ickebruk och vilka avsikter den brukande individen har beträffande sitt framtida bruk, dvs om han eller hon har för avsikt att sluta eller ej. Det enda undantaget utgörs av villkoret om ett tidigare försök att sluta för att vara kvalificerad för det tredje stadiet (beslutande). Sutton (1996) har påpekat att detta villkor medför en mindre anomali att den individ som söker förändra sitt beteende för första gången aldrig kan befinna sig i modellens tredje steg. 
Det kanske mest centrala egenskapen hos Prochaska och DiClemetes modell utgörs av dess sekventiella struktur. Om vi ansluter oss till Simpson och Joe's (op. cit.) tolkning av modellens första steg som nära relaterade till individens perception av det beteende som är aktuellt (jfr. problemperception), utgör den sekventiella strukturen en egenskap med betydande intresse också för vår diskussion av motivationsbegreppet.

Det finns emellertid skäl att påpeka att den sekventiella strukturen inte är särdeles elaborerad hos de kategorier som kan erhållas via ett användande av "the staging algoritm». Den mest påtagliga tröskeln är givetvis övergången från beslutande till handling, dvs från bruk till icke-bruk. Däremot framstår övergången till det femte stadiet, upprätthållandet som inträder efter 6 månaders abstinens, som mer eller mindre helt substanslös och arbiträr, det finns inget som helst skäl varför vi skall betrakta individens förändringsprocess som kvalitativt annorlunda vid en specifik tidpunkt (Sutton, op. cit.). Övriga avgränsingar baseras på individens intentionella hållning visavi det framtida bruket. Här är det väl främst övergången från pre-begrundande till begrundande som kan göra anspråk på att utgöra en mer reell kvalitativ förändring i den meningen att individen går från ett tillstånd där han eller hon överhuvudtaget inte reflekterar över att göra ett seriöst försök att sluta bruka till ett tillstånd där abstinens utgör ett faktiskt alternativ. Vid empiriska studier har det dock visat sig att denna typ av tydliga gränser är svåra att identifiera. Kraft och Sutton (1997) konstaterar i en undersökning av norska rökare (dagligt rökande, ej behandlingssökande) att drygt 60 procent av dessa kunde betecknas som "pre-begrundare» om Prochaska och DiClementes algoritm användes (här måste vi dock komma ihåg att då undersökning gällde aktiva rökare, kan endast de tre första kategorierna i modellen komma ifråga). Detta resultat jämfördes därefter med mätresultat från en wintentionskala« avsedd att mäta förekomst och intensitet beträffande intention att sluta röka. Det visade sig då att en dryg tredjedel av de individer som uppgivit att de var "ganska" eller "mycket säkra på att de skulle sluta röka» var klassificerade som "pre-begrundare».

Också i övrigt redovisar Kraft och Sutton (op. cit.) resultat som ifrågasätter giltigheten i modellens sekventiella struktur.Genom att studera fördelningen av individens skäl för respektive mot rökning via en reviderad version av "Smoking Decisional Balance Scale» kunde de konstatera att fördelning låg mycket långt ifrån den som kunde förväntas med utgångspunkt från Prochaska och DiClementes modell. Det var endast mellan pre-begrundare och de båda övriga kategorierna som en tydlig skillnad beträffande fördelningen av skäl för och emot att sluta röka kunde konstateras. Kraft och Sutton konstaterar: "Consequently, one could reduce the staging algoritm to a single question: Are you thinking about quitting in the next 6 months?"

\section{Motivation och ambivalens}

Ambivalens brukar vanligen beskrivas som ett tillstånd där individen vid ett och samma tillfälle omfattar motstridiga känslor eller värderingar beträffande ett givet objekt. Uttryckt på ett annat sätt skulle vi kunna säga att ambivalens konstitueras av en kon- 
flikt mellan olika motiv - att ambivalens är en motivationskonflikt När det gäller missbruk är det i huvudsak fråga om en ambivalens i förhållande till en given drog eller berusning/påverkan. Många inflytelserika forskare på området lägger stor vikt vid ambivalensfenomenet och placerar det i centrum av missbruksproblematiken (jfr Miller \& Rollnick 1991; Orford, 1985). Ambivalens identifieras ibland också som den huvudsakliga orsaken bakom problem med bristande motivation hos klienter i missbruksbehandling (Davies, 1979).

Inom "motivational interviewing " betonas att en bearbetning av individens ambivalens utgör ett av de mest centrala inslagen (Miller och Rollnick, op.cit.). Motivationsarbetet skall förse individen med argument som leder till att »jämviktsläget" (jfr »decisional balance») förändras på ett sådant sätt att individen lämnar sitt ambivalenstillstånd till förmån för ett tillstånd där beslut kan fattas. I Prochaska och DiClementes språkbruk sammanfaller ambivalens till stora delar med den "begrundande» fasen, då olika för- och nackdelar vägs mot varandra.

Det torde inte råda någon större tvekan om att ambivalens utgör ett centralt inslag $i$ problem som ofta bokförs under rubriken "bristande behandlingsmotivation«. Det är t.ex. inte ovanligt att bristande stabilitet $\mathrm{i}$ en individs utfästelser om deltagande i en given behandling betraktas som ett motivationsproblem. ${ }^{3}$ Det är däremot inte helt klart på vilket sätt ambivalensens grundläggande dynamik skall förstås.

3 Detta problem belyses t.ex. i Socialberedningens betänkande (SOU 1987:22) då man diskuterar på vilka grunder en missbrukares utfästelser kan tagas ad notam.
Delvis i polemik mot många av de dominerande uppfattningarna på området har Ainslie (1992) föreslagit att ambivalensfenomenet har två grundläggande tolkningsmöjligheter. Ainslie hävdar att en konflikt mellan olika motiv - dvs. en ambivalent situation - antingen kan förstås som en följd av att värderingen av de möjliga handlingsalternativen ligger mycket nära varandra eller att värderingen av de olika alternativen varierar över tid på ett sådant sätt att rangordningen mellan dem ändras. I det förra fallet kan det faktiska resultatet bli att ingen handling kommer till stånd, detta då inget entydigt motiv kan etableras, eller att handlingsutfallet blir beroende av yttre slumpmässiga faktorer och därmed också i en viss mening arbiträrt. I det senare fallet ser Ainslie motivationskonflikten som ett uttryck för att individens diskontering av två givna alternativ har en sådan form att de båda alternativen över tid kommer att byta plats med varandra.

Begreppet diskontering avser normalt den reduktion en individ gör av ett framtida värde. Den individ som föredrar att få 100 kronor omedelbart i handen istället för att få 250 kronor om ett år, gör sitt handlingsval med utgångspunkt från en kraftig diskontering av de 250 kronor. Formellt innebär detta att värdet av de 250 kronor reduceras så kraftigt att de vid tidpunkten för erbjudandet representerar ett värde som underskrider 100 kronor. Om vi arrangerar om erbjudandet till att gälla 100 kronor om 6 månader och 250 kronor om ett år, är det tänkbart att individen ifråga säger sig välja 250 kronor, men att han eller hon vid tidpunkten för möjligheten att välja 100 kronor (dvs. efter 6 månader) åter väljer att omedelbart 
konsumera $100 \mathrm{kr}$ (som vid denna tidpunkt inte är diskonterade, detta då är omedelbart tillgängliga). I de fall diskonteringfunktion producerar denna typ av förändringar i individens preferenser brukar den betecknas som hyberbolisk, detta i motsats till s.k. exponentiell diskontering som innebär att en individs värdering av två alternativ förblir stabil också över tid. Ainslie har visat att denna typ av diskonteringsfunktion med fördel kan användas för att förklara ett brett spektrum av ambivalensfenomen.

En missbrukares bristande motivation kan i detta perspektiv förstås som ett problem relaterat till frånvaron av en rimlig stabilitet $\mathrm{i}$ individens preferenser. Det är också möjligt att identifiera en individs bristande motivation till enbart diskonteringsfaktorns storlek. En mycket kraftig diskontering av framtiden leder till ett handlingsmönster som i huvudsak relaterar till nuet. För att frågan om en förändring av en individs drog-eller alkoholvanor skall framstå som meningsfull måste också de i tiden utsträckta konsekvenserna tilldelas fakticitet. Graden av diskontering av de långsiktiga och negativa effekterna kan anföras som en förklaring såväl till varför ett missbruk etableras som till varför det kvarstår, trots uppenbara negativa konsekvenser för individen.

\section{Motivation och rationalitet}

I den utsträckning missbruksbeteende inte betraktas som kvalitativt skilt från andra typer av handlande blir i de flesta fall också motivationsproblematiken mindre komplicerad. ${ }^{4}$ I Beckers och Murphys (1988) be-

4 I den utsträckning Ainslies (1992) hyberbolis- römda modell för ett rationellt missbruk framträder en aktör som överhuvudtaget inte kommer att efterfråga behandling.

Agenten i Beckers och Murphys modell är inte enbart rationell i den meningen att hans eller hennes preferenser är stabila över tid, det är en agent som också är utrustad med en fullständig kunskap om de framtida konsekvenserna av det egna handlandet. En agent med dessa egenskaper kommer att med utgångspunkt från såväl de omedelbara som diskonterade framtida effekter välja det handlingsalternativ som ger maximalt utbyte. Detta innebär att även en individs val av missbruk utgör en utbytesoptimerad handling och att individen av detta skäl inte själv inte önskar avbryta missbruket. ${ }^{5}$

Det existerar dock också andra rationali-

ka diskonteringsmodell inordnas under en rationell rubrik utgör densamma ett undantag. Avgörande för huruvida vi skall betrakta en person med en hyperbolisk diskonteringsfunktion som rationell eller ej, är det perspektiv vi väljer att anlägga på tidsdimensionens betydelse för en definition av rationalitet. I den utsträckning en standard-defintion används, dvs. att ett handlande är rationellt i den utsträckning en individ vid varje givet tillfälle handlar i enlighet med sina preferenser (se t.ex. Frank 1992), faller också Ainslies modell innanför ett rationellt perspektiv. Det är först då vi kräver att individens handlingar också skall ha ett samband över tid som Ainslies modell innefattar ett icke-rationellt beteende.

5 Den rationelle missbrukare önskar inte abstinens men inser att denna önskan är en följd av de konsumtionserfarenheter han eller hon har tillägnat sig över tid. I Becker \& Murphys (1988) modell konfronteras individen med en vara som har den egenskapen att ju mer som har konsumerats av densamma i förfluten tid desto mindre blir utbytet vid varje given konsumtionsnivå i nuet. Till detta kommer att ök-

Bergmark \& Oscarsson: Behandlingsmotivation och tvångsvård 
tetebaserade - men mer pragmatiskt orienterade - modeller med relevans för missbruksproblematik. Den kanske mest inflytelserika av dessa modeller är den av Fishbein och Ajzen lanserade »Behavioral intention model" som också är känd som »the theory of reasoned action " (Ajzen och Fishbein, 1980). Denna modell är i sig en elaborering av den mer grundläggande s.k. SEU-modellen (subjective expected uitility) och postulerar därmed också en central förbindelse mellan individens evaluering av den nytta som följer på en given handling och individens val av handlingar. Fishbein och Ajzens modell kompletterar dock denna grundläggande struktur med en komponent som innefattar individens uppfattning beträffande hur signifikanta andra förhåller sig till det faktum att individen utför den aktuella handlingen. Denna komponent betecknas som "subjektiv norm" och kommer tillsammans med individens egen evaluering av handlingens följder att utgöra modellens bestämningspunkter för individens intention, vilken i sin tur leder till handling.

I sin generella form tycks denna modell peka på en möjlighet att påverka individens motivation genom en manipulering av den subjektiva normen. Den tydliga förändringen av rökvanor under det senaste decenniet torde utgöra ett exempel som med fördel skulle kunna analyseras utifrån Fishbein och Ajzens modell. Men också frånvaron av motivation till förändring, i den form som detta tar sig uttryck inom LVM-vården, kan gö-

ningen av det omedelbara utbytet, via en ökning av den nuvarande konsumtionen, blir större ju mer han har konsumerat i förfluten tid. ras begriplig inom denna modell. Den marginaliserade missbrukarens subjektiva norm kan tänkas vara särdeles svår att påverka då den ofta torde vara relaterad till en subkultur med andra värderingar än de som är gängse inom normalsamhället.

\section{Motivationsarbete inom tvångsvården}

Vi skall nu övergå till att kortfattat försöka ange några hållpunkter för på vilket sätt motivationsarbetet inom den nuvarande LVMvården av missbrukare kan relateras till de teoretiska ledmotiv vi har behandlat i det föregående. Det empiriska underlaget för denna diskussion härrör i huvudsak från ett pågående projekt om motivationsarbetets former och innehåll inom den tvångsbaserade missbrukarvården. Som en del av detta projekts inledande fas genomförde vi under 1996 en enkätundersökning av sådana enheter inom svensk missbrukarvård som vid tidigare undersökningar angivit att motivationsarbete utgjorde ett väsentligt inslag $\mathrm{i}$ deras verksamhet (Bergmark och Oscarsson 1994). ${ }^{6}$

Granskningen av tidigare undersökningar ledde till en identifikation av 74 enheter. Som väntat visade en närmare undersökning att några av dessa trots allt inte ansåg sig bedriva något motivationsarbete under det att andra enheter var nedlagda eller överhuvudtaget inte bedrev missbrukarvård. Den slutgiltiga undersökningspopula-

6 Utöver detta användes också kartläggningar av öppenvården som genomförts av socialstyrelsen och förteckningar över LVM-institutioner vid Statens institutionsstyrelse. 
tionen kom att omfatta 61 enheter vilka samtliga besvarade enkäten

Vi vill understryka att detta material inte kan, och inte heller är avsett att, förmedla mer extensiva och innehållsmättade beskrivningar av motivationsarbete. ${ }^{7}$ Trots detta vill vi dock hävda att data av nominell natur, vilka utgör huvuddelen av de data som är aktuella här, också kan användas vid en bedömning av motivationsarbetets karaktär och inriktning vid de enheter som besvarade vår enkät.

Vid tidpunkten för vår enkät fanns 23 LVM-institutioner varav ca hälften angav att de bedrev sitt arbete med utgångspunkt i en ideologi eller teoretisk tradition som kan betraktas som etablerad. ${ }^{8}$ De övriga institutionerna angav antingen att motivationsarbetet bedrevs med utgångspunkt från en individuell planering för varje individ eller med avstamp i mer allmänna idéer om mänsklig förändring eller missbruk (en tro på människans förmåga till förändring; missbruk som flykt från verkligheten, etc.). De artikulerade alternativen utgjordes av ett psykodymaniskt, ett AA-inspirerat (Anonyma Alkoholisters 12 steg) och ett kognitivt/beteendeinriktat perspektiv.

Vid jämförelse mellan de frivilliga insti-

7 Det huvudsakliga syftet med enkäten var att etablera en empirisk bas för ett urval av enheter som skulle studeras mer intensivt och att belysa huruvida det fanns tydliga skillnader mellan motivationsarbete inom den frivilliga vården och LVM-vården.

8 Här användes en öppen fråga. Detta då frågor med fasta svarsalternativ framstår som mindre lämpliga att använda när ett undersökningsobjekt karaktäriseras av en frånvaro av en metoddiskurs. tutionerna (som utgjorde en nästan lika stor grupp som tvångsvården) och LVM-institutionerna framstår fördelningen av utgångspunkter som tämligen likartad i de båda grupperna. Också i jämförelse med fördelningen av behandlingsideologier inom institutionsvården som helhet (Bergmark och Oscarsson 1994) kan vi se tydliga paralleller mellan de olika grupperna. Den primära skillnaden utgörs av den relativa frånvaron av miljöterapeutiska utgångspunkter bland motivationsenheterna.

De AA-inriktade enheterna var sammantaget mer benägna än övriga grupperingar att betona de teoretiska kunskapernas betydelse för motivationsarbetet. Detta framstår möjligen som något förvånande utifrån mer generella förväntningar. Med avseende på omfattningen av den befintliga teorimassan för de olika inriktningarna, torde den psykodynamiska inriktningen vara ett mer plausibelt alternativ. Men en tendens åt detta håll, dvs. en mer accentuerad teoretisk komponent hos enheter med en verksamhet baserad på AA:s principer, har också observerats i studier av institutionell missbrukarvård i allmänhet (Bergmark och Oscarsson, op. cit.). Den teoretiska komponenten framstår i dessa fall i huvudsak som en betoning av en generell metodik snarare än en teoretiserade hållning i det praktiska arbetet. En tolkning som ligger nära till hands är att de AA-inspirerade enheternas teoretiska orientering i första hand utgör en indikation på att dessa enheter betonar en professionell hållning. En professionalitet som i sin tur återföras på den s.k. Minnesotamodellens kodifiering av AA:s principer i form av en behandlingsmodell.

De AA-inspirerade enheterna anger i hu-

Bergmark \& Oscarsson: Behandlingsmotivation och tvångsvård 
vudsak AA-litteratur som särskilt betydelsefull för det egna motivationsarbetet. I ett fall anges dock också ett verk från en författare med central betydelse för utvecklingen av "Motivational interviewing" (se ovan), vilket utgör ett mindre frågetecken med avseende på vilken praktisk tillämpning denna metod kan få inom ett ramverk av såväl AAprinciper som yttre tvångsmedel. $\mathrm{Av}$ vår tidigare diskussion av "Motivational interviewing" framgick att denna metod, åtminstone tidvis, har framställts som oförenlig med vissa inslag i såväl AA:s («botten-erfarenhet" som en förutsättning för förändring) som Minnesota-modellens praktik (konfrontations tekniker avsedda att påskynda etableringen av en "botten-erfarenhet").

Dock anger endast en enhet med AA-inriktning att de de facto använder sig av konfrontationstekniker i sitt arbete. Denna typ av arbetsmetod är istället relativt vanlig bland de enheter som arbetar utifrån en individuell planering för varje klient, eller andra ej klassificerade inriktningar. Där hälften av enheterna säger sig använda konfrontationstekniker i sitt arbete.

De psykodynamiskt inriktade enheterna uppvisar vissa likheter med de kognitivt inriktade enheterna. Den relativa frånvaron av en betoning av teoretiska komponenter, som vi ovan betecknade som något förvånande för den förstnämnda grupperingen, finns också hos de kognitivt inriktade enheterna. Denna tendens understöds också av det faktum att båda grupperingarna sammantaget har en högre värdering av livserfarenheters betydelse än de teoretiska kunskapernas betydelse för arbetet.

De enheter som angivit att motivationsarbetet sker utifrån individuell planering $\mathrm{i}$ varje enskilt fall representerar troligen en relativt heterogen grupp i den meningen att denna hållningen inte nödvändigtvis också representerar en frånvaro av ett teoretiskt perspektiv på klienternas motivationsproblematik. En enhet anger att den differentierade hållningen $\mathrm{i}$ arbetet med klienterna delvis är en följd av rekryteringsprocessen och frånvaron av ett inflytande över denna process. Här antyds dels att enheten saknar inflytande över vilka klienter de faktiskt får och att problematiken hos dessa är så divergerande att ingen etablerad metodik kan anges.

\section{Motivationsarbete eller behandling?}

Sammantaget tycker vi oss kunna konstatera att ungefär hälften av LVM-institutionerna saknar angivelser som kan betraktas som rimliga indikationer på att de bedriver ett någorlunda sammanhållet och vetenskapligt/professionellt etablerat arbete med sina klienter. Även om de övriga enheterna, dvs. de med ett motivationsarbete med utgångspunkt från psykodynamisk, kognitiv/beteende-teoretisk och AA-inspirerad teoribildning, uppfyller vad vi skulle kunna beteckna som ett "artikuleringskrav", är detta dock inte en tillräcklig information för att vi med fog skall kunna påstå att dessa enheter också har en någorlunda koherent praktik på detta område. ${ }^{9}$ Ett visst stöd för frånva-

9 Inom det forskningsprogram där föreliggande artikel utgör ett första steg har vi studerat innehållet i motivationsarbetet mer detaljerat hos dessa tre typer av inriktningar. Resultaten förväntas bli redovisade i avhandlingsform under nästkommande år 
ron av artikulering kan vi också identifiera $\mathrm{i}$ en av SIS utgiven katalog (LVM-hem och särskilda ungdomshem, 1996) där var och en av institutionerna har fått ange inriktning och innehåll för det egna arbetet. I det stora hela överensstämmer dessa beskrivningar ganska väl med resultat från vår enkät.

Vi kan också konstatera att det inte tycks föreligga någon tydligt inflöde av de teorier som vi identifierat i genomgången av motivationsbegreppets innehåll. Ingen enhet hänvisar till Prochaska och DiClementes modell (1984) och endast i ett fall förekommer en referens till "Motivational interviewingw. Samtidigt är det dock inte självklart att dessa perspektiv kan eller bör praktiseras inom ramen för ett yttre tvång. »Motivational interviewing" beskrivs ofta på ett sätt som betonar individens ansvar "Responsibility for change is left with the individual" (Miller och Rollnick 1991, s. 52). Samtidigt bygger den också på frånvaron av en påtaglig professionell auktoritet $\mathrm{i}$ arbetet »The least desirable situation, from this viewpoint, is one in which the counselor is arguing that the client has a problem and needs to change, while the client is defending an opposite viewpoint." (Miller och Rollnick op. cit., s. 58). Det torde vara uppenbart att båda dessa beskrivningar pekar i riktning mot att "Motivational interviewing" inte kan eller bör tillämpas inom ett tvångskontext. $\mathrm{Nu}$ kompliceras emellertid giltigheten i en sådan slutsats av att det finns andra omständigheter som helt eller delvis kan betraktas som ett stöd för motsatsen - att det är möjligt att praktisera "Motivational interviewing" inom ett tvångskontext. Ett första och tämligen trivialt skäl för detta utgörs av den relativa löslighet som kan sägas karaktä- risera "Motivational inteviewing" som metod..$^{10}$ I normalfallet anges ofta enbart ett antal generella principer: Att uttrycka empati; att förstärka diskrepansen mellan nuvarande beteende och mer långsiktiga mål: undvika att argumentera; följa med i klientens motstånd och föreslå nya perspektiv istället för att föreskriva dem; stödja klienten tro på sin egen förmåga (Miller och Rollnick, op. cit.) Dessa principer torde inte, åtminstone inte på en nominell nivå, vara omöjliga att iscensätta inom vissa delar av den befintliga LVM-vården.

Det är också möjligt att betrakta påståenden om att "Motivational interviewing" passar särskilt bra för individer som är ambivalenta eller motvilliga till förändring (Miller och Rollnick, op. cit.) som ett stöd för metodikens användbarhet inom tvångsvården. Slutligen är det också möjligt att peka på praktiska exempel från verksamheter som praktiserat "Motivational interviewing" med klienter som befunnit sig i en formell tvångssituation (Garland och Dougher 1991).

En oklarhet som kvarstår när det gäller motivationsarbetet vid LVM-institutionerna är huruvida detta arbete skiljer sig från

10 Den s.k. MET-modellen (Motivational Enhancement Therapy) utgör ett exempel på en arbetsmetodik som kan betraktas som mycket nära besläktad med såväl tankegångarna bakom Prochaska och DiClementes modell (op. cit) som "Motivational interviewing". Denna metodik har i vissa sammanhang givits en relativt tydlig utformning (Project MATCH Research Group 1993) men kan p.g.a. sin korta tidsutdräkt (4 sessioner i det fall som refereras här och den starka betoningen av klientens eget ansvar knappast betrakta som kompatibel med de yttre förutsättningarna för LVM-vård. 
reguljärt behandlingsarbete och om så fallet, vad som konstituerar en sådan skillnad? Som vi påpekade i inledningen av denna artikel framstår det som relativt klart att den nuvarande LVM-vården i en formell mening bygger på en distinktion mellan motivationsarbete och behandling (SOU 1987:22). Detta är också ett förhållande som delvis återspeglar sig i svaren på vår enkät. Ett antal enheter kommenterar explicit att de arbetar med motivation och inte med behandling. Men å andra sidan kan vi inte identifiera några tydliga tecken på ett sådan distinktion när det gäller de teoretiska utgångspunkterna för motivationsarbetet. I allt väsentligt har de mer artikulerade beskrivningarna tydliga relationer till etablerade behandlingsperpektiv på området, under det att motsvarande förbindelser när det gäller motivationsteoretiska komponenter i huvudsak saknas. Betecknade för sakernas läge är den tvetydighet som är möjlig att utläsa i den av SIS utgivna katalogen som kortfattat beskriver de olika enheterna inom LVM-vården och vården vid de särskilda ungdomshemmen (LVM-hem och särskilda ungdomshem, 1996). Under rubriken "Behandlingsinnehåll" (i det avsnitt som avser LVM-hemmen) anger här 16 enheter att de bedriver motivationsarbete, 6 enheter att de bedriver såväl motivations- som behandlingsarbete och en enhet anger att de enbart bedriver behandling. Till vissa delar kan kanske detta återföras på det faktum att vissa enheter "skriver utu sina klienter till behandling inom den egna enheten. $\AA$ andra sidan har dock ett flertal enheter också »låsbara» behandlingsavdelningar vilket pekar i riktning mot att behandling inte enbart sker inom ramen för 27 i LVM.
Denna oklarhet huruvida det finns någon egentlig skillnad mellan motivationsarbete och behandling är emellertid ingalunda enbart begränsad till LVM-vården - frågan framstår också som oklar även inom de mest etablerade teoretiska perspektiven på motivation. Så ger t.ex. Miller och Rollnick (op. cit.) inga ledtrådar till om de uppfattar »Motivational interviewing" som behandlingsintervention eller ej. I samband med beskrivningen av tankegångarna bakom den s.k. Metmodellen (Motivational Enhancement Therapy, se not 10) inom Project MATCH antyds dock några möjliga utgångspunkter för en distinktion mellan de båda begreppen. Dels anges en skillnad beträffande interventionens syfte. Till skillnad från behandlingsinterventioner där interventionen i sig utgör den förändringsgenerande komponenten beskrivs MET som riktad mot individens egna resurser "Rather than relying on therapy sessions as the primary locus of change, the therapist seeks to mobilize the clients personal resources"(Project MATCH Research Group 1993, s. 1133). En följd av detta syfte är att interventionen får en mycket begränsad omfattning. Inom Project MATCH omfattade MET i sin helhet endast fyra sessioner. Även om dessa båda kriterier på intet sätt kan betraktas som invändningsfria när det gäller grunderna för en distinktion mellan begreppen behandling och motivation, kan de ändå ha ett visst värde vid en granskning av LVMvårdens tvetydighet på denna punkt. Dessa kriterier antyder att LVM-vårdens svårigheter att endast omfatta motivationsarbete skulle kunna betraktas som en följd av att dess tidsutdräkt är alltför omfattande och att tvångskontexten som sådant negerar snarare än bejakar individens egna resurser. 


\section{Avslutande anmärkningar}

Om vi tillåter oss att påtagligt komprimera den analys som vi har redogjort för i det föregående, kan en sammanfattande slutsats utformas i följande fyra punkter:

- Den vetenskapliga/professionella diskursen kring motivationsproblematik hos missbrukare är i hög utsträckning koncentrerad till två, sinsemellan nära besläktade, teoretiska modeller - "Motivational interviewing" (Miller och Rollnick, 1991) och den "transteoretiska modellen" för förändringsprocesser (Prochaska och DiClemente, 1984).

- Ingen av dessa modeller kan betraktas som "empiriskt säkerställd» i den meningen att de understöds av entydiga resultat från empiriska undersökningar.

- I allt väsentligt genomförs motivationsarbetet inom LVM-vården utan hänvisningar till dessa modeller. ${ }^{11}$

- I de fall LVM-enheterna identifierade en teoretisk bas för sitt motivationsarbete (vilket drygt hälften av enheterna gjorde) utgjordes dessa av behandlingsideologier av konventionellt snitt.

Det är först vid en analys av mer detaljerade data beträffande motivationsarbetet inom LVM-vården som det blir möjligt att ge mer kvalificerade svar på hur motivationsarbetet faktiskt gestaltas och legitimeras. I avvaktan på denna typ av analys vill vi avslutningsvis peka på de möjligheter till en precisering av LVM-vårdens motiverande arbete som trots allt kan sökas hos några av de teoretiska inriktningar som diskuterats i det föregående.

Även om vare sig »Motivational interviewing" eller den "transteoretiska modellen" inte kan sägas utgöra några särdeles entydiga styrinstrument för ett konkret motivationsarbete delar de båda en begreppslig kärna som rimligtvis borde kunna tjäna som en utgångspunkt för en analys av motivationsarbetet inom LVM-vården också för de praktiker som skall genomföra arbetet. Det tredimensionella perspektiv på motivationsbegreppet som föreslagits av Simpson och Joe (1993) knyter tydligt an till de båda modellernas grundläggande struktur samtidigt som det preciserar motivationsarbetes objekt till: missbrukarens problemperception, upplevelse av hjälpbehov och inställning till aktuell behandlingsform. En precisering som, åtminstone på ett teoretiskt plan, lägger grunden för en identifikation av olika typer av skäl för en individs reservationer inför erbjudanden om behandling.

\footnotetext{
11 Det enda undantaget utgörs av att en enhet nämner en bok som kan relateras till „Motivational interviewing".
}

Bergmark \& Oscarsson: Behandlingsmotivation och tvångsvård 


\section{Summary \\ Motivation and coercive treatment for substance abusers.}

In 1989 an amendment to the Care of Alcoholics and Drug Abusers Act extended the time limits for coercive treatment from two months (with a possible extension of two months) to six months. This was done explicitly in the belief that an extended period of coercive treatment was needed in order to motivate the alcoholic or drug abuser to seek further treatment voluntarily. Thus - at least on a formal level - motivational work became the most important task for the professionals within the units for coercive treatment.

However, it has remained unclear what the theoretical foundation for this type of motivational work actually is, or at least, claimed to be. Furthermore, it is also uncertain to what extent the practice of "motivation interventions" within the units for coercive treatment can be regarded as governed by articulated principles with reasonable support from the majority of personnel at each treatment unit.

The aim of the present article is two-fold. A first objective consists of identifying and discussing scientifically based perspectives on motivation. In contrast to the most common type of review article, where the uncovering of a whole field constitutes a major task, we are here focusing on an identification of the predominate perspectives within the scientific discourse. This work is intended to function as a stepping-stone for the second objective: to produce an assessment of the methods that are used within the treatment units that deliver coercive treatment, i.e. to establish to what extent the practice of motivational work within coercive treatment settings can be said to be in congruence with the scientific discourse on motivational work for individuals with alcohol and drug problems.

\section{Litteratur}

Ainslie. G. (1992) Picoeconomics. Cambridge: Cambridge University Press.

Ajzen, I. \& Fishbein, M (1980) Understanding Attitudes and Predicting Social Behaviour. Englewood Cliffs, New Jersey: Prentice-Hall,.

Bateson, G. (1973) Steps to an ecology of Mind. St Albans: Palladin,.

Becker, G. \& Murphy, K (1988) A theory of rational addiction. Journal of Political Economy, 96, 675700 .

Bergmark. A \& Oscarsson, L (1994) Behandling inom den socialtjänstbaserade institutionsvården. Omfattning och innehaill. Stockholm. Addiction Research Group, Stockholms Universitet
Davies. P. (1979) Motivation, responsibility and sickness in the psychiatric treatment of alcoholism. British Journal of Psychiatry, 134, 449458.

De Leon, G. \& Jainchill, N. (1986) Circumstances, motivation, readiness and suitability as correlates of treatment tenure. Journal of Psychoactive Drugs, 18:3, 203-208.

De Leon,, G., Melnick, G., Kressel, D., Jainchill, N. (1994) Circumstances ; Motivation, Readiness, and Suitability (The CMRS Scales) Predicting Retention in Therapeutic-Community Treatment. American Journal of Drug and Alcohol abuse, 20:4, 495-515.

DiCicco, L., Unterberger, H. \& Mack, J.E., (1978), 
Confronting denial: An alcoholism intervention strategy. Psychiatric Annals, 8, 596-606.

Frank, R. H. (1992) The Role of Moral Sentiments in the Theory of Intertemporal Choice. I: Loewenstein, G. \& Elster, J., red,: Choice over Time. New York: The Russel Sage Foundation.

Garland, R.J. \&Dougher, M.J. (1991) Motivational Intervention in the Treatment of Sex Offenders. In: Miller, W.R. \& Rollnick, S., red,: Motivational Interviewing. NewYork: Guilford Press.

Järvinen, M \& Skretting, A, (1994) Missbruk och Tvångsvård. Helsingfors, Nordiska nämnden för alkohol- och drog forskning.

Lehto, J. (1994) Involuntary treatment of people with substance related problems in the Nordic Countries. I: Järvinen , M. \&Skretting, A. , red, Missbruk och Tvångsvård. Helsingfors, Nordiska nämnden för alkohol- och drog forskning.

Johnson, V.E. (1973) I'll quit tomorrow. New York: Harper \& Row.

Kraft, P. \& Sutton, (1997) The transtheoretical model of behaviour; are the stages qualitatively different? Opublicerat manuskript.

Maxvell, M., (1981) The Alcoholics Anonymous Experience. New York: McGraw-Hill,.

Miller, W.R. (1985) Motivation for Treatment: A Review With Special Emphasis on Alcoholism.. Psychological Bulletin, 98:1, s. 84-107.

Miller, W.R. \& Rollnick, S. (1991) Motivational interviewing. New York: Guilford Press.

Nationalencyklopedin (1995) Volym 13. Stock- holm: Bra Böckers förlag

Orford, J. (1985) Excessive appetites: A psychological view on addictions. New York, Wiley

Project MATCH Research Group (1993) Project MATCH: Rationale and Methods for a Multisite Clinical Trial Matching Patients to Alcoholism Treatment. Alcoholism: Clinical and Experimental Research, 17:6, s. 1130-1145.

Prochaska, J.O. \& DiClemente, C.C. (1984) The transtheoretical approach, Crossing traditional boundaries for change. Homewood: Dorsey Press.

Simpson, D.D. \& Joe, G.W. (1993) Motivation as a predictor of early dropout from drug abuse treament. Psychotherapy, 30:2, 357-368.

Statens Institutionsstyrelse (1996) LVM-hem och särskilda ungdomshem. Stockholm: Statens institutionsstyrelse.

Stockwell, T. (1992) Models of change, heavenly bodies, and weltanschauungs, British Journal of Addiction, 82, 830-832.

SOU 1987:22. Missbrukarna, socialtjänsten och tvånget. Stockholm: Allmänna förlaget.

Sutton, S. (1996) Can 'stages of change' provide guidance in the treatment of addictions? A critical examination of Proshchaska and DiClemete's model. In Edwards. G. \& Dare, C., red,: Psychoterapy, psychological treatments and the addictions. Cambridge: Cambridge University Press

Tännsjö, T. (1995) Tvång i vården. Stockholm: Thales. 